AEROJET NUCLEAR SYSTEMS COMPANY SACRAMENTO, CALIFORNIA
T'O:

FROM :

ENCLOSURE:
R. G. Ackerman

A. J. Mihanovich
This report was prepared NOE

sponsored by the United as an account of work the United States nor States Government. Neither Research and States nor the United States Energy their emplopment Administration, nor any of subcontractors, nor any of their contractors, warranty, express or their employees, makes any liability or responsibilityplied, or assumes any legal or usefulness of any informa the accuracy, completeness process disclosed, information, apparatus, product or infringe privately owned rights.

\title{
SUBJECT : \\ Statistical Analysis of 347 Stainless Steel and Hastelloy-X Fatigue Test Results
}

DATE : 18 October 1971

N8200:M3053:A.JM:jak

\author{
COPIES TO: \\ J. Pickering, J. H. Ramsthaler, C. W. Robson, \\ H. Spaletta, J. L. Watkins, File
}

(1) Fatigue Test Data for Type 347 Stainless Stee1

(2) Fatigue Test Data for Hastelloy-X (3) Sumnarized Resuits of the Anajysis - 347 Stainless
Steel

(4) Summarized Results of the Analysis - Hastelloy-X

\section{PURPOSE OF THE ANALYSIS}

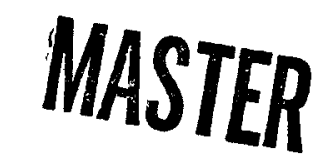

A series of fatigue tests were performed on specimens of 347 stainless steel and Hastellcy-X at three temperature levels: $1000^{\circ} \mathrm{F}, 1400^{\circ} \mathrm{F}$, and $1600^{\circ} \mathrm{F}$. The purpose of the statistical analysis of the resultant test data was to devalop estimates of the relationships between total axial strain and the fatigue life (in terms of cycles to failure) at each of the three temperature levels for both materials. In addition, of interest were the corresponding 99/95 limits (numbers of cycles which $99 \%$ of the specinens exposed to $a$ fixed strain level could be expected to survive with a confidence level of $.95)$.

\section{SUMMARY OF RESULTS}

The results of the statistical analysis, Enclosures (3) and (4), indicate that the relationships between $\log$ percent total. strain and $10 g$ fatigue life could be adequately represented by straight lines in all cases except one (at $1 C 00^{\circ} \mathrm{F}$ the 347 stainless steel results were found to be best represented by a quadratic relationship between $l o g$ percent total strain and log fatigue life). At the two lower temperature levels $\left(1000^{\circ} \mathrm{F}\right.$ and $\left.1400^{\circ} \mathrm{F}\right)$ the 347 stainless steel specimen generally exhibited longer fatigue lives than the Hastelloy $\mathrm{X}$ specimens both in terms of mean expected life and $99 / 95$ life. At the $1600^{\circ} \mathrm{F}$ temerature level, however, the two materials exhibited essentially equivalent mean lives while the Hastelloy-X specimens exhisited slightly higher 99/95 lives.

In these calculations heat-to-heat variations were treated as a random variable. Under this assumption the 347 stainless steel results were felt 


\section{DISCLAIMER}

This report was prepared as an account of work sponsored by an agency of the United States Government. Neither the United States Government nor any agency Thereof, nor any of their employees, makes any warranty, express or implied, or assumes any legal liability or responsibility for the accuracy, completeness, or usefulness of any information, apparatus, product, or process disclosed, or represents that its use would not infringe privately owned rights. Reference herein to any specific commercial product, process, or service by trade name, trademark, manufacturer, or otherwise does not necessarily constitute or imply its endorsement, recommendation, or favoring by the United States Government or any agency thereof. The views and opinions of authors expressed herein do not necessarily state or reflect those of the United States Government or any agency thereof. 


\section{DISCLAIMER}

Portions of this document may be illegible in electronic image products. Images are produced from the best available original document. 

R. G. Ackerman

to satisfy the T.D. $69-28$ and T.D. $69-37$ requirements for Class A material data at all three temperature levels. The Hastelloy-X results satisfied the Class A data requirements at the $1000^{\circ} \mathrm{F}$ and $1600^{\circ} \mathrm{F}$ levels but not at the $1400^{\circ} \mathrm{F}$ level. With reference to these conclusions, it should be noted that there is a lack of clear agreement at the present time on the precise interpretation of the material data classifications, especially as they apply to fatigue test data. As a result these conclusions are subject to change if changes in interpretation occur.

\section{METHOD OF ANALYSIS}

The fatigue test data which served as the basis of the analysis is presented in Enclosures (1) and (2). Three heats of material (designated as $\hat{A}_{\text {, }} \underline{B}_{2}$ and C) were available for 347 stainless steel while only two heats (designated as $\mathrm{D}$ and $\mathrm{E}$ ) were available for Hastelloy-X. The test results consisted of the fatigue lives (in terms of cycles-to-failure) observed at various applied levels of percent total strain.

Plots of the data indicated that in all cases except one the relationship between $\log$ fatigue life and $\log$ strain level was reasonably linear. The exception was the 347 stainless steel results at $1000^{\circ} \mathrm{F}$ where there was sufficient non-1inearity in the data to justify a second order (quadratic) model to express the relationship between $\log$ fatigue 1 ife and $\log$ strain level.

Regression analyses were performed at each of the temperature levels for each of the heats of the two materials. These analyses were performed using the G.E. Mark I library program NULFT\$***, which provides least squares fits to sets of data and the associated means and variances.

The remainder of the analysis was performed using methods described in R101-NRP-502, Sampling for Fatigue Test. The methods described in this procedure consist essentially of the following steps:

For a given material at a defined temperature level,

1. For each heat, develop a curve fit to $\log$ fatigue life $\left(\mathrm{N}_{f}\right)$ vs $10 \mathrm{~g}$ percent strain level (s).

2. Pooling the results of the individual heats.

(a) Develop an overall relationship between $\log \mathrm{N}_{f}$ and $\log \mathrm{s}$.

(b) Develop an overa11 estimate of within heat variation, $\hat{\sigma}_{W}^{2}$.

3. Estimate the heat-to-heat variation, $\hat{\sigma}_{L}^{2}$.

4. Calculate the combined variation, $\hat{\sigma}^{2}$, of $\hat{\sigma}_{W}^{2}$ and $\hat{\sigma}_{L}^{2}$. 
5. Calculate the degrees of freedom, $f$, associated with $\hat{\sigma}^{2}$.

6. For each strain level of interest,

(a) Calculate the log expected (or mean) fatigue life using the fitted equation relating $\log$ fatigue life and $\log$ strain.

(b) Calculate the effective sample size, $\mathrm{n}_{e}$, associated with the strain level.

(c) Determine the tolerance factor, $K$, associated with the values of $\mathrm{P}=.99, \gamma=.95, \mathrm{n}_{\mathrm{e}}$ and $\mathrm{f}$ from appropriate tables or using the G.E. Mark II program TFAC**.

(d) Calculate the $\log$ of the lower $99 / 95$ 1imit as follows: $\log 99 / 95$ 1imit $=\log$ expected 1ife - Kô

(e) Take the antilog of the $\log 99 / 95$ limit to determine the lower 99/95 limit on fatigue life at the specified strain level of interest.

The above procedure was followed for each of the materials at each of the temperature levels. The results of the calculations are presented in Enclosures (3) and (4). Although desirable, no combining (pooling) of results among the several temperature levels of a material was possible, due to the highly dissimilar results observed at the several temperature levels.

Technical Directives $69-28$ and $69-37$ provide the rules and criteria to be used in the classification of materials data into various categories, e.g., A, B, C, D. Unfortunately, following the implementation of the directives, many questions have arisen with respect to their intent and interpretation. For example, it is not clear whether or not lot-to-lot variation should be considered as a part of the random variation, nor is it clear how the directives apply to fatigue data analyses, etc. These problems are currently being investigated by ANSC and SNSO-C representatives. As a result of these questions there is no clear cut answer with respect to the proper classification of the results of the subject analyses.

If the lot-to-lot variation is treated as a random source of variation, then all of the 347 stainless steel results satisfy the requirements of Technical Directives 69-28 and 69-37 with respect to "A" data. This conclusion is also based on the assumption that normal regression analysis techniques can be utilized to estimate the effective sample size at each strain level (an assumption with no clear direction from T.D. 69-28). The results for Hastelloy$\mathrm{X}$, however, satisfy the criteria of T.D. 69-28 with respect to "A" data only at the $1000^{\circ} \mathrm{F}$ and $1600^{\circ} \mathrm{F}$ levels. The $1400^{\circ} \mathrm{F}$ results should be classified at some lesser material category.

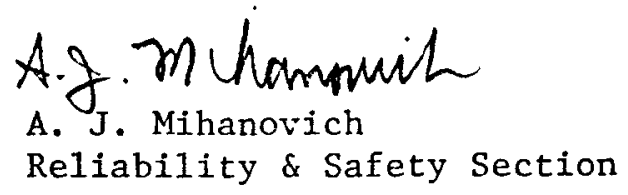


FATIGUE TEST DATA FOR TYPE 347 STAINLESS STEEL

$1000^{\circ} \mathrm{F}$

\begin{tabular}{|c|c|c|c|c|c|}
\hline \multicolumn{2}{|c|}{ HEAT A } & \multicolumn{2}{|c|}{ HEAT (B) } & \multicolumn{2}{|l|}{ HEAT C } \\
\hline CYCLES & & CYCLES & & CYCLES & \\
\hline & PERCENT & To & PERCENT & TO & PERCENT \\
\hline FAILURE & TOTAL & FAILURE & TOTAL & FAILURE & TOTAL \\
\hline $\mathrm{N}_{\mathrm{f}}$ & STRAIN & $\mathrm{N}_{f}$ & STRAIN & $\mathrm{N}_{\mathrm{f}}$ & STRAIN \\
\hline 132 & 4.92 & 124 & 4.94 & 155 & 4.93 \\
\hline 170 & 4.97 & 142 & 4.94 & 164 & 4.93 \\
\hline 172 & 4.89 & 150 & 4.92 & 174 & 4.92 \\
\hline 300 & 2.92 & 327 & 2.91 & 336 & 2.95 \\
\hline 401 & 2.92 & 339 & 2.92 & 372 & 2.91 \\
\hline 403 & 2.96 & 405 & 2.89 & 397 & 2.92 \\
\hline 1856 & 1.49 & 1590 & 1.48 & 1369 & 1.50 \\
\hline 1975 & 1.48 & 1877 & 1.38 & 1952 & 1.49 \\
\hline 2251 & 1.46 & 2536 & 1.39. & 2443 & 1.47 \\
\hline & 11 & & $?$ & & \\
\hline
\end{tabular}


ENCLOSURE (1)

Page 2.

FATIGUE TEST DATA FOR TYPE 347 STAINLESS ST'EEL

$$
1400^{\circ} \mathrm{F}
$$

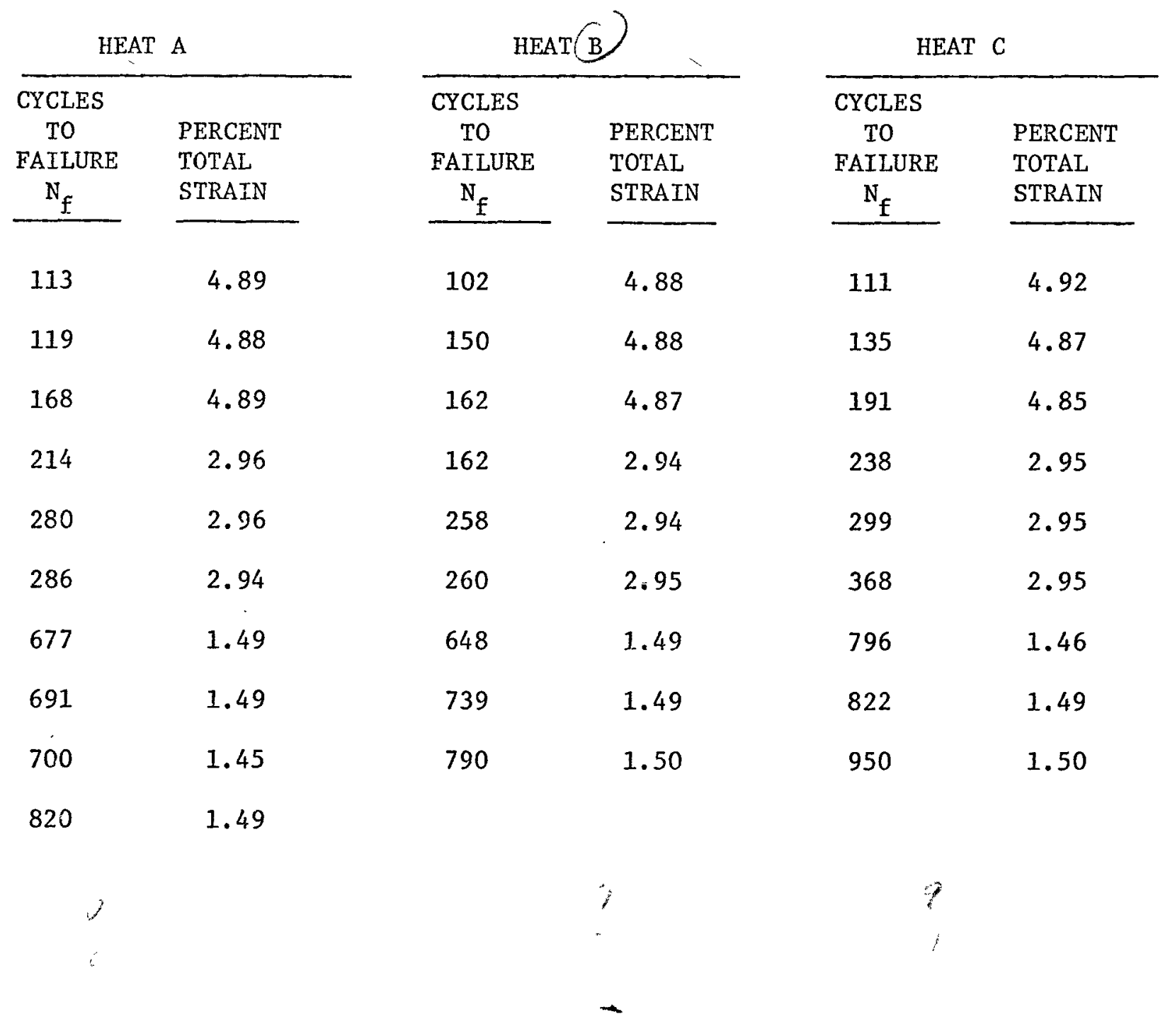


ENCLOSURE (1)

Page 3.

FATIGUE TEST DATA FOR TYPE 347 STAINUESS STEEL

$$
1600^{\circ} \mathrm{F}
$$

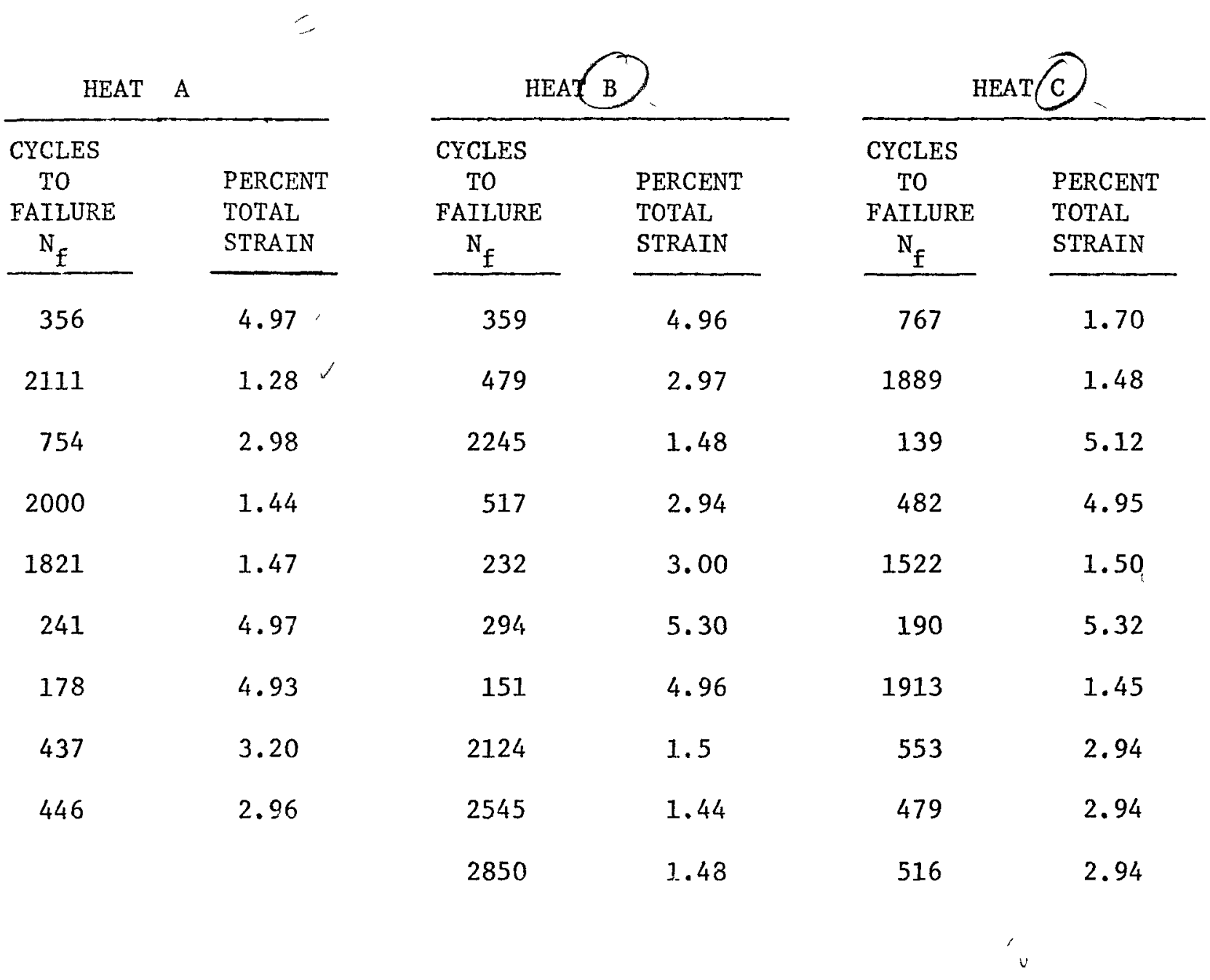


ENCLOSURE (2)

N8200:M3053

FATIGUE TEST DATA FOR HASTELLOY-X

$$
1000^{\circ} \mathrm{F}
$$

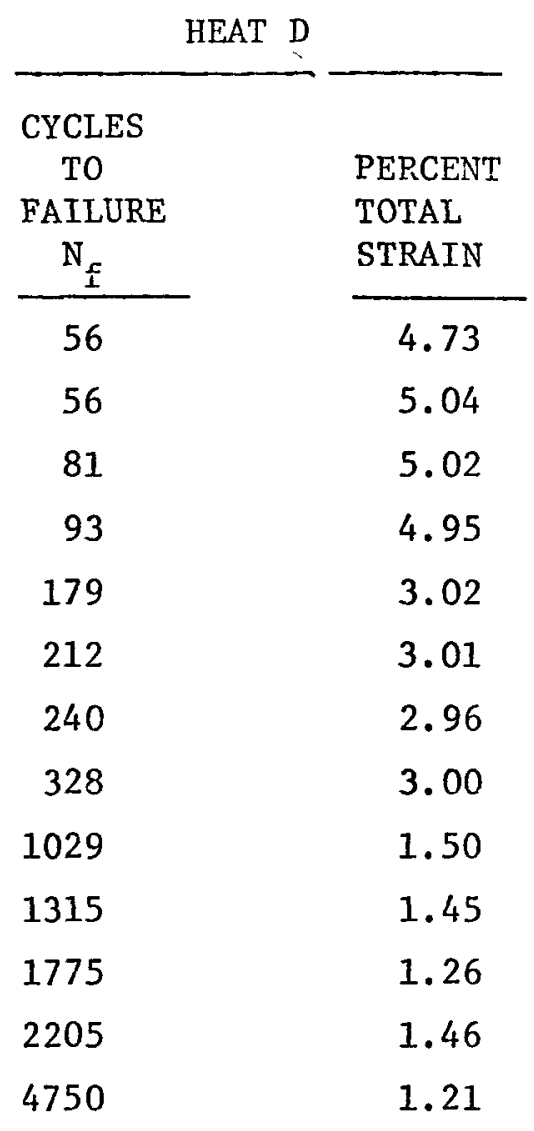

\begin{tabular}{ccc}
\multicolumn{2}{c}{ HEAT E } \\
$\begin{array}{c}\text { CYCLES } \\
\text { TO } \\
\begin{array}{c}\text { FAILURE } \\
N_{f}\end{array}\end{array}$ & $\begin{array}{l}\text { PERCENT } \\
\text { TOTAL } \\
\text { STRAIN }\end{array}$ \\
\cline { 1 - 1 } 30 & & 4.90 \\
51 & & 4.85 \\
98 & & 4.75 \\
104 & & 4.86 \\
104 & & 4.96 \\
194 & & 2.95 \\
238 & & 2.94 \\
241 & & 3.00 \\
289 & & 2.96 \\
846 & & 1.49 \\
1589 & 1.50 \\
1644 & 1.50 \\
2193 & 1.40
\end{tabular}


ENCLOSURE (2)

Page 2.

FATIGUE TEST DATA FOR HASTELLOY-X

$1400^{\circ} \mathrm{F}$

HEAT D

\begin{tabular}{l}
\hline CYCLES \\
TO \\
FAILURE \\
$\mathrm{N}_{\mathrm{f}}$ \\
\hline
\end{tabular}

99

108

136

137

203

230

251

283

865

923

929

964

D

(1)

PERCENT

$$
\text { TOTAL }
$$

STRAIN

\subsection{2}

4.88

4.93

4.88

2.96

2.96

2.98

2.94

1.47

1.50

1.47

1.47
HEAT E

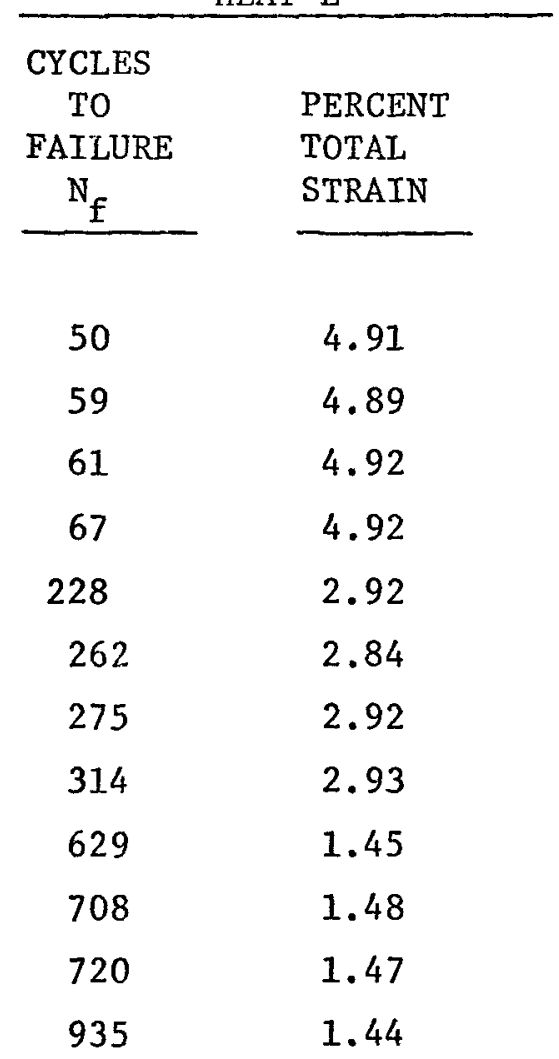


ENCLOSURE (2)

Page 3.

FATIGUE TEST DATA FOR HASTELLOY-X

$1600^{\circ} \mathrm{F}$

HEAT D

\begin{tabular}{l} 
CYCLES \\
TO \\
FAILURE \\
$\mathrm{N}_{\mathrm{f}}$ \\
\hline
\end{tabular}

129

227

784

1731

469

522

2283

473

277

193

1805

1601

185

255

2249

621
PERCENT

TOTAL

STRAIN

6.64

3.95

1.96

1.53

3.00

2.95

1.48

3.00

4.96

5.01

1.59

1.49

5.19

4.95

1.51

2.96
HEAT E

\begin{tabular}{|c|c|}
\hline \multicolumn{2}{|l|}{ CYCLES } \\
\hline TO & PERCENT \\
\hline FAILURE & TOTAL \\
\hline$N_{f}$ & STRATN \\
\hline
\end{tabular}

2278

1.51

596

2.96

185

5.01

194

4.97

479

3.00

1998

1.53

219

4.96

172

5.27

425

3.00

981

1.65

301

3.34 
ENCLOSURE (3)

N8200:M3053

\section{SUMMARIZED RESULTS OF THE ANALYSIS}

\section{TYPE 347 STAINLESS STEEL}

\section{BEST FIT TREND LINES*}

$1000^{\circ} \mathrm{F}$

HEAT A: $\quad \log N_{f}=8.89237-3.56974 \log s+.73028(\log s)^{2}$

HEAT B :

$\log N_{f}=8.59799-3.08173 \log s+.490895(\log s)^{2}$

HEAT C:

$\log N_{f}=8.80809-3.4971 \log s+.7357(\log s)^{2}$

COMBINED :

$\log N_{f}=8.76615-3.38286 \log s+.652278(\log s)^{2}$

$1400^{\circ} \mathrm{F}$

HEAT A :

$\log N_{f}=7.13058-1.43088 \log \mathrm{s}$

HEAT B:

$\log N_{f}=7.09576-1.43405 \log s$

HEAT $C$ :

$\log N_{f}=7.33845-1.50819 \log s$

COMBINED :

$$
\log N_{f}=7.18620-1.45675 \log s
$$

$1600^{\circ} \mathrm{F}$

HEAT A: $\quad \log N_{f}=8.11979-1.63778 \log \mathrm{s}$

HEAT B: $\quad \log N_{f}=8.40969-1.90621 \log \mathrm{s}$

HEAT C: $\quad \log \mathrm{N}_{f}=7.93392-1.54246 \log \mathrm{s}$

COMBINED: $\quad \log \mathrm{N}_{\mathrm{f}}=8.155662-1.697473 \log \mathrm{s}$

* $s=$ Percent total strain. All $\log$ valves are $\log _{e^{*}}$ 
SUMMARIZED RESULTS OF THE ANALYSIS

TYPE 347 STAINLESS STEEL

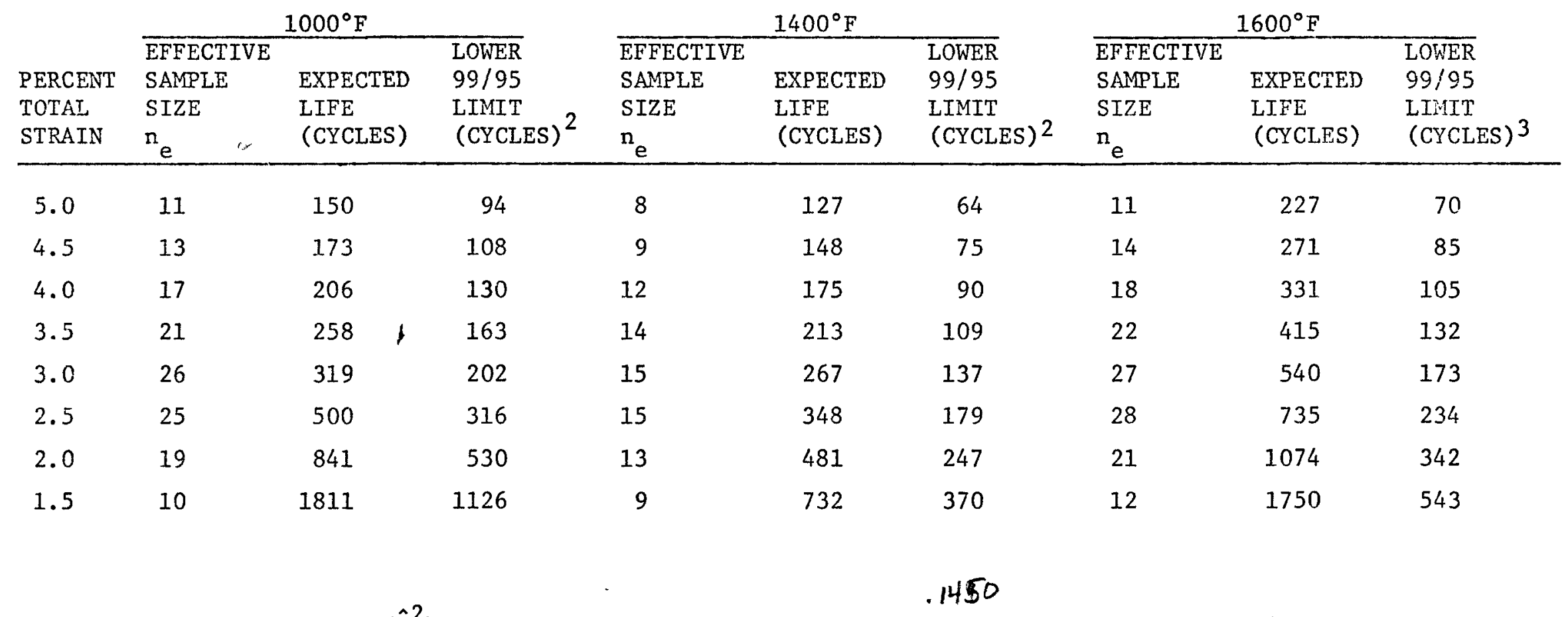

1. The random variation $\left(\hat{\sigma}^{2}\right)$ used in this calculation equals 0.021019 and is based on 24 degrees of freedom.

2. The random variation $\left(\hat{\sigma}^{2}\right)$ used in this calculation equals 0.04109 and

$.3605 \quad .305$ and is based on 24 degrees of

3. The random variation $\left(\hat{\sigma}^{2}\right)$ used in this calculation equals 0.129948 and is based on 24 degrees of freedom. 
SUMMARIZED RESULTS OF THE ANALYSIS

HASTELLOY-X

BEST FIT TREND LINES*

$1000^{\circ} \mathrm{F}$

HEAT D: $\quad \log \mathrm{N}=8.37132-2.61229 \log \mathrm{s}$

HEAT E: $\quad \log \mathrm{N}_{\mathrm{f}}^{\mathrm{f}}=8.28726-2.56736 \log \mathrm{s}$

CORBINED: $\quad$ Log $\mathrm{N}_{f}=8.32929-2.589825 \log \mathrm{s}$

$1400^{\circ} \mathrm{F}$

HEAT D: $\quad \log \mathrm{N}_{f}=7.45134-1.71998 \log \mathrm{s}$

HEAT E: $\quad$ Log $\mathrm{N}_{f}=7.50419-2.0555$ Log $\mathrm{s}$

COMBINED: $\quad \log \mathrm{N}_{\mathrm{f}}=7.477765-1.88774 \log \mathrm{s}$

$1600^{\circ} \mathrm{F}$

HEAT D: $\quad \log \mathrm{N}_{\mathrm{f}}=8.23435-1.80178 \log \mathrm{s}$

HEAT E: $\quad \log \mathrm{N}_{f}=8.22282-1.85988 \log \mathrm{s}$

COMBINED: $\quad \log N_{f}=8.229653-1.82545 \log s$

- $* s=$ percent total strain. All $\log$ values are $\log _{e}$. 
SUMARIZED RESULTS OF THE ANALYSIS

HASTELLOY $\mathrm{X}$

\begin{tabular}{|c|c|c|c|}
\hline & \multicolumn{3}{|c|}{$1000^{\circ} \mathrm{F}$} \\
\hline & Effective & & Lower \\
\hline & Sample & Expected & $99 / 95$ \\
\hline Tota1 & Size & Life & Limit \\
\hline Strain & & (Cycles) & $(\text { Cycles })^{2}$ \\
\hline
\end{tabular}

\begin{tabular}{lll} 
& \multicolumn{3}{c}{$1400^{\circ} \mathrm{F}$} \\
\hline Effective & & Lower \\
Sample & Expected & $99 / 95$ \\
Size & Life & Limit \\
$\mathrm{n}_{\mathrm{e}}$ & (Cycles) & (Cycles) $^{2}$
\end{tabular}

\begin{tabular}{lll}
\multicolumn{3}{c}{$1600^{\circ} \mathrm{F}$} \\
\hline Effective & & Lower \\
Sample & Expected & $99 / 95$ \\
Size & Life & Limit \\
$n_{e}$ & (Cycles) & (Cycles) $^{3}$
\end{tabular}

\begin{tabular}{|c|c|c|c|c|c|c|c|c|c|}
\hline 5.0 & 11 & 64 & 19 & 3 & 85 & 17 & 12 & 198 & 103 \\
\hline 4.5 & 13 & 84 & 26 & 3 & 103 & 21 & 15 & 241 & 125 \\
\hline 4.0 & 16 & 114 & 35 & 3 & 129 & 26 & 19 & 299 & 156 \\
\hline 3.5 & 21 & 162 & 50 & 4 & 166 & 34 & 24 & 381 & 200 \\
\hline 3.0 & 24 & 241 & 76 & 4 & 222 & 4.5 & 26 & 505 & 266 \\
\hline 2.5 & 24 & 386 & 121 & 4 & 314 & 64 & 24 & 704 & 370 \\
\hline 2.0 & 18 & 688 & 214 & 3 & 478 & 95 & 16 & 1058 & 552 \\
\hline 1.5 & 10 & 1450 & 436 & 3 & 823 & 164 & 9 & 1789 & 915 \\
\hline
\end{tabular}

1. The random variation $\left(\hat{\sigma}^{2}\right)$ used in this calculation equals 0.131013 and is based on 22 degrees of freedom.

2. The random variation $\left(\hat{\sigma}^{2}\right)$ used in this calculation equals 0.075376 and is based on 4 degrees of freedom.

3. The random variation $\left(\hat{\sigma}^{2}\right)$ used in this calculation equals 0.0408 and is based on 23 degrees of freedom. 